Journal An-Nafs: Kajian Penelitian Psikologi https://ejournal.iai-tribakti.ac.id/index.php/psikologi e-ISSN: 2549-6166 p-ISSN: 2528-0600 DOI: $10.33367 /$ psi.v5i2.1036

$\begin{array}{cccc}\text { Submitted: } & \text { Revised: } & \text { Accepted: } & \text { Published: } \\ \text { 17-02-2020 } & 26-05-2020 & 14-06-2020 & 01-12-2020\end{array}$

\title{
QUARTERLIFE CRISIS PADA MASA DEWASA AWAL DI PEKANBARU
}

\author{
Icha Herawati ${ }^{1}$, Ahmad Hidayat ${ }^{2}$ \\ 1ichaherawati@psy.uir.ac.id, ${ }^{2}$ ahmadhidayat@psy.uir.ac.id \\ Universitas Islam Riau
}

\begin{abstract}
The transition from adolescents to adult challenges is different from the challenges of life in the previous development process. Towards the age of 25, individuals face a new life such as work, marital status, and mindset. The quarter-life crisis is a phenomenon that is common in individuals aged 20-30 years old. The crisis of a quarter of a century, that's how the term counts with individuals who attend 25 years. The quarter-life crisis experiences' by individuals grew up. This research is descriptive quantitative research. The subjects in this study consist of 236 adults in Pekanbaru who attended for 20-30 years. The retrieval of data in this study uses the quarter-life crisis scale. The results showed that the early adult individual quarter-life crisis in Pekanbaru reached $43.22 \%$, increasing the high category of $27.97 \%$. The results showed the fact that factors affecting the quarterly life crisis estimated as gender, status, and occupation. The conclusions of this study show that adults in Pekanbaru who spend a quarter of life issued by women, are single and do not have jobs.
\end{abstract}

Keyword : Quarter life crisis, dewasa awal

\begin{abstract}
Abstrak
Peralihan dari remaja menjadi dewasa terdapat tantangan tersendiri yang berbeda dengan tantangan hidup pada proses perkembangan sebelumnya. Menuju usia 25 tahun individu menghadapi kehidupan baru seperti pekerjaan, status pernikahan, dan perubahan pola pikir. Quarter life crisis adalah sebuah fenomena yang umum terjadi pada individu direntang usia 20-30 tahun. Krisis seperempat abad, begitu pengertian istilah ini yang memang berkaitan dengan individu yang berusia 25 tahun. Penelitian ini bertujuan untuk melihat gambaran Quarter life crisis yang dialami oleh individu yang beranjak dewasa di Pekanbaru. Penelitian ini merupakan penelitian kuantitatif deskriptif. Subjek pada penelitian ini terdiri dari 236 individu dewasa awal di Pekanbaru yang berusia 20-30 tahun. Pengambilan data dalam penelitian ini menggunakan skala Quarter life crisis. Hasil penelitian menunjukkan bahwa Quarter life crisis individu dewasa awal di Pekanbaru berada pada tahap sedang yaitu $43.22 \%$, dilanjutkan pada kategori tinggi sebesar 27.97\%. Hasil penelitian juga menunjukkan bahwa faktor yang mempengaruhi Quarter life crisis diantaranya adalah jenis kelamin, status dan pekerjaan. Kesimpulan dari penelitian ini menunjukkan individu dewasa awal di Pekanbaru yang mengalami Quarter life crisis didominasi oleh wanita, berstatus belum menikah dan belum memiliki pekerjaan.
\end{abstract}

Kata Kunci : Quarter life crisis, dewasa awal 
Icha Herawati \& Ahmad Hidayat | Quarterlife Crisis

\section{PENDAHULUAN}

Salah satu tahap perkembangan manusia adalah menjadi Dewasa. Dalam kajian ilmu psikologi perkembangan tahap Dewasa juga dibagi menjadi tiga tahapan yaitu dewasa awal, dewasa menengah dan dewasa akhir. Penelitian ini berfokus pada tahap perkembangan dewasa awal. Menjadi dewasa merupakan tahap puncak perkembangan kesehatan kehidupan, kebugaran fisik dan memiliki potensi untuk menjadi tahap perkembangan yang sangat positif dibandingkan remaja. Pada dewasa awal memiliki peluang yang besar untuk mengeksplorasi diri tetapi juga menghadapi tantangan yang besar (Halfon dkk., 2017). Tahap dewasa awal disebutkan tahap seseorang yang sudah melewati masa remaja dan dianggap mampu hidup secara mandiri (Kirsh dkk., 2013). Individu dewasa awal dianggap mampu menentukan masa depan dan juga dianggap mampu mengatur kehidupannya secara mandiri (Wardhani, 2002). Hal ini dikarenakan seseorang harus melakukan penyesuaian dengan peran barunya yaitu dalam pernikahan atau pekerjaan. Apabila seorang individu tidak dapat mengatasinya, maka akan menimbulkan masalah. Ketika seseorang berumur 20-an (sebelum 30-an), kondisi emosionalnya tidak terkendali.

Fenomena saat ini dalam sebuah kehidupan selalu muncul pertanyaan-pertanyaan dari masyarakat. Dalam menjadi dewasa awal, salah satu tugas perkembangan yang harus dijalani adalah menghadapi dunia sosial. Faktanya, untuk menjadi dewasa awal banyak pertanyaan yang muncul dari masyarakat, seperti kapan wisuda, kapan menikah, kapan mendapatkan pekerjaan, dan kapan lainnya yang sepertinya tidak akan pernah habis. Pertanyaan pertama yang sering muncul yaitu ketika dimasa akhir perkuliahan, individu tersebut akan banyak menghadapi ditanya kapan wisuda. Hal ini membuat para individu yang akan menginjaki masa dewasa untuk harus selalu siap menghadapi tantangan sosial yang memandang mereka sebagai orang dewasa. Salah satu permasalahan psikologis pada tahap dewasa awal yang berapa tahun terakhir banyak diperbincangkan yaitu mengenai Quarter Life Crisis.

Quarterlife crisis adalah sebuah istilah baru yang berkaitan dengan tahap perkembangan sosioemosional manusia. Krisis seperempat abad, begitu pengertian istilah ini yang memang berkaitan dengan individu yang berusia seperempat abad, usia 25 tahun. Menuju usia 25 tahun, individu biasanya telah menghadapi kehidupan baru seperti pekerjaan, status pernikahan, dan perubahan pola pikir yang lebih matang dari remaja menuju dewasa. Kondisi tersebut juga membuat individu berada pada puncak pendewasaan diri yang memasuki usia 25tahun mempertanyakan hidupnya, ragu akan pilihan, bingung atas apa yang dijalani, mulai meninjau masa lalu, apa saja yang telah 
dilakukan selama hidup dan mempertanyakan kehidupan seperti apa yang akan dijalaninya dimasa depan (Revitasari, 2018).

Robbins dan Wilner pada tahun 2001 merupakan ahli yang pertama kali mengemukakan istilah dari Quarter-life crisis berdasarkan hasil penelitian mereka terhadap kaum muda di Amerika. Julukan yang mereka berikan kepada kaum muda tersebut sebagai "twentysomethings", yakni individu yang baru saja meninggalkan kenyamanan hidup sebagai pelajar dan mulai memasuki dunia nyata, memulai kehidupan dengan tuntutan untuk bekerja atau menikah. Perasaan-perasaan yang mengarah ke Quarter life crisis ini terjadi pada akhir masa remaja, ketika individu mendekati akhir-akhir masa perkuliahan dan mempersiapkan diri untuk "dunia nyata," baik saat di sekolah menengah atau perguruan tinggi. Kelulusan yang akan datang sering memicu kepanikan tentang masa depan seorang individu, yatitu perasaan ketakutan alami dari kejutan budaya dan perbedaan lingkungan yang akan datang.

Terdapat banyak mitos dan fakta mengenai quarter life crisis, diantaranya menurut Primala (2017) adalah merasa cemas akan pilihan hidup, perempuan tidak perlu sekolah tinggi-tinggi, mulai membuat komitmen, berteman secara kualitas, bukan kuantitas. Noor, H (2018) mengatakan seseorang yang ada dalam krisis ini kehilangan motivasi hidup, merasa gagal, kehilangan kepercayaan diri dan makna hidup, bahkan menarik diri dari pergaulan. Hal yang paling nyata dirasakan orang yang mengalami quarterlife crisis adalah kegalauan akan hidupnya yang terasa monoton, khawatir berlebihan tentang masa depan dan menyesali serta mempertanyakan keputusan hidup yang sudah diambil.

Pengenalan istilah quarter-life crisis oleh Robbins dan Wilner juga disertai dengan beberapa karakteristik umum yang menjadi tanda bahwa individu mungkin sedang mengalami quarter-life crisis. Beberapa tanda tersebut adalah sebagai berikut, (1) individu merasa tidak mengetahui keinginan dan tujuan hidupnya; (2) pencapaian pada usia 20 -an tidak sesuai dengan harapan; (3) takut akan kegagalan; (4) tidak ingin merelakan masa kecil dan masa remaja berakhir; (5) takut tidak mampu menempatkan pilihan yang tepat untuk sebuah keputusan, dan (6) cenderung membandingkan pencapaian dan keadaan diri sendiri dengan orang lain sehingga membuat diri merasa tidak mampu dan tidak berguna (Robinson dkk., 2013).

Tanda lainnya ketika seseorang mengalami quarter-life crisis dapat dilihat dari kategori quarter-life crisis itu sendiri. Adapun kategori tersebut adalah sebagai berikut, (1) the locked-out form, yaitu ketika individu merasa tidak mampu untuk memiliki peran sebagai orang dewasa; dan (2) the locked-in form, yaitu ketika individu merasa terjebak dalam perannya sebagai orang dewasa. Kedua model ini memang tidak dapat dikatakan 
Icha Herawati \& Ahmad Hidayat | Quarterlife Crisis

universal tetapi setidaknya cukup representatif dalam memberikan gambaran mengenai keadaan seseorang saat mengalami quarter-life crisis (Robinson dkk., 2013).

Menjadi dewasa juga memiliki tantangan tersendiri yaitu juga dikatakan sebagai masa sulit bagi seorang individu karena pada masa ini seseorang dituntut untuk melepaskan ketergantungannya terhadap orang tua dan berusaha untuk dapat berdiri sendiri. (Basis, 2014) menemukan bahwa salah satu aspek yang dapat meningkatkan kualitas hidup dewasa muda adalah dengan bekerja. Penelitian ini juga menyebutkan salah satu tugas perkembangan dewasa awal adalah mendapatkan pekerjaan. Memilih pekerjaan yang tepat adalah salah satu upaya seseorang dalam mengokohkan kemandirian baik secara finansial maupun psikologis. Penemuan oleh (Wardhani, 2002) menemukan bahwa dengan memiliki pekerjaan merupakan titik tolak seorang individu yang baru saja memasuki kehidupan nyata untuk memulai hidupnya sebagai individu mandiri yang dapat menentukan sendiri masa depannya dan mengatur kehidupan.

Temuan lain terdapat dalam penelitian (Vasquez, 2015) yang melaporkan bahwa individu pada awal masa dewasa memang rentan mengalami quarter-life crisis sebagai akibat dari tekanan pekerjaan, hubungan, dan berbagai harapan untuk menjadi orang dewasa yang benar-benar sukses. Sementara itu, Macrae (2011) dalam penelitiannya melaporkan bahwa banyak dewasa muda pada usia 20-30an mengalami serangan panik dan merasa meragukan kemampuan dirinya sendiri untuk menjalankan kehidupan pada masa dewasa sebagai akibat dari krisis ini. Berdasarkan sekilas paparan dan hasil penelitan di atas dapat dikatakan bahwa masa transisi dari remaja menuju dewasa adalah sebuah transisi yang kompleks. Terdapat banyak stressor yang mengarah pada berbagai kesulitan, sehingga individu merasa terjebak dan kehilangan arah dalam masa dewasanya. Individu mulai merasa sulit menghadapi dunia, sulit mengatur emosi, hingga mulai mempertanyakan apakah kehidupannya yang akan dijalani telah berada di jalan yang benar atau tidak.

Berdasarkan fenomena diatas, peneliti tertarik untuk melihat isu perkembangan menghadapi dewasa awal di Pekanbaru. Apakah anak muda pekanbaru menghadapi Quarter life crisis ataupun tidak, sehingga berdasarkan penelitian ini nantinya akan dapat melihat isu perkembangan sosioemosional yang dihadapi individu dewasa awal di Pekanbaru.

\section{METODE}

Penelitian ini merupakan penelitian kuantitatif deskriptif. Metode pengampulan data yang digunakan adalah skala. Terdapat satu skala yang digunakan, yaitu skala quarter life crisis, yang dirancang dengan menggunakan model skala likert yang memiliki empat 
alternative jawaban, yaitu Sangat Setuju (SS), Setuju (S), Tidak Setuju (TS) dan Sangat Tidak Setuju (STS). Populasi penelitian ini adalah individu sebanyak 221.797 dewasa awal yang berusia 20-30 tahun di Pekanbaru. Teknik Pengambilan sampel menggunakan metode purposive sampling. Sampel dengan tujuan ini melibatkan prosedur sampling di mana sekumpulan subjek yang mempunyai ciri-ciri tertentu saja yang dipilih sebagai responden penelitian berdasarkan pengetahuan dan tujuan khusus penelitian. Dalam penelitian ini, peneliti akan menyebarkan skala penelitian secara bebas kepada responden yang berada di dalam kawasan masyarakat Kota Pekanbaru namun responden tersebut harus memenuhi ciri-ciri yang ditetapkan oleh peneliti. Ciri-ciri yang ditetapkan adalah individu laki-laki dan perempuan yang berusia 20-30 Tahun, berodmisili d Kota Pekanbaru, dan bersedia menjadi responden pada penelitian ini. Analisis data penelitian menggunakan analisis statistik deskriptif dan analisis faktor menggunakan IBM statistic 23.

\section{PAPARAN HASIL}

Penelitian ini untuk mendeskripsikan gambaran Quarterlife Crisis pada dewasa Awal di Pekanbaru. Penelitian ini menggunakan skala Quarterlife Crisis yang disusun oleh Peneliti. Berdasarkan tabel 1 menjelaskan blue print dari skala Quarterlife Crisis. Jumlah aitem penelitian pada skala Quarterlife Crisis berjumlah 27 aitem.

Tabel 1

Blueprint skala Quarterlife Crisis

\begin{tabular}{|c|c|c|c|c|}
\hline \multirow{2}{*}{ No } & \multirow{2}{*}{ Aspek } & \multicolumn{2}{|l|}{ Aitem } & \multirow{2}{*}{ Jumlah } \\
\hline & & Favorable & Unfavorable & \\
\hline 1 & Personal & $1,2,4,5,6,7,8,9$ & 3 & 9 \\
\hline 2 & Social & $10,11,12,13,14,15,16,17,18$ & & 9 \\
\hline 3 & Career & $20,21,23,24$ & 19,22 & 6 \\
\hline 4 & Relationship & 27 & $\begin{array}{l}25,26 \\
\text { Jumlah }\end{array}$ & $\begin{array}{c}3 \\
27\end{array}$ \\
\hline
\end{tabular}

Analisis statistik deskriptif dan inferensial dilakukan pada penelitian ini berdasarkan pengumpulan data yang telah dilakukan kepada 236 individu dewasa awal di Pekanbaru yang berusia 20-30 tahun, dan bersedia menjadi partisipan dalam penelitian ini. Informasi yang telah dirangkum dalam profil demografi adalah jenis kelamin, pekerjaan, pendapatan bulanan, status dan pendidikan terakhir. Hasil analisis statistik deskriptif dapat dilihat pada Tabel dibawah ini. 
Icha Herawati \& Ahmad Hidayat | Quarterlife Crisis

Tabel 2

Data Demografi Subjek Penelitian

\begin{tabular}{lcc}
\hline \multicolumn{1}{c}{ Demografi } & Jumlah & Presentase \\
\hline Jenis Kelamin & & \\
Pria & 76 & $32.2 \%$ \\
Wanita & 160 & $67.8 \%$ \\
Pendidikan Terakhir & & \\
SMA & 84 & $35.6 \%$ \\
Sarjana (S1) & 120 & $50.8 \%$ \\
Magister (S2) & 32 & $13.6 \%$ \\
Pekerjaan & & \\
Kerja Tetap & 115 & $48.7 \%$ \\
Freelance & 49 & $20.8 \%$ \\
Belum Bekerja & 72 & $30.5 \%$ \\
Status & & \\
Belum Menikah & 125 & $53 \%$ \\
Bepacaran & 63 & $26.7 \%$ \\
Menikah & 48 & $20.3 \%$ \\
\hline
\end{tabular}

Berdasarkan tabel 2 diketahui jumlah responden wanita lebih banyak (67.8\%) daripada responden pria (32.2\%). Respoden pada penelitian ini rata-rata paling banyak berada pada jenjang pendidikan Strata Satu (S1) yaitu 50.8\%, memiliki pekerjaan tetap sebanyak $48.7 \%$ dan bersatatus belum menikah sebesar $53 \%$.

Selain analisis demografi, pada penelitian ini juga ditemukan tingkat Quarter life crisis pada dewasa awal di Pekanbaru. Tingkatan tersebut dibuat dalam 5 tingkatan, yaitu Sangat tinggi, tinggi, sedang, rendah dan sangat rendah.

Tabel 3

Rentang Nilai dan Kategorisasi Quarterlife Crisis

\begin{tabular}{|c|c|c|c|}
\hline Kategori & Rentang Nilai & Frekuensi & Persentase $\%$ \\
\hline Sangat tinggi & $X \geq 96.47$ & 24 & $10.17 \%$ \\
\hline Tinggi & $82.71 \leq X<96.47$ & 66 & $27.97 \%$ \\
\hline Sedang & $68.96 \leq X<86.71$ & 102 & $43.22 \%$ \\
\hline Rendah & $55.19 \leq X<68.96$ & 35 & $14.83 \%$ \\
\hline \multirow[t]{2}{*}{ Sangat rendah } & $X \leq 55.19$ & 9 & $3.82 \%$ \\
\hline & Total & 236 & $100 \%$ \\
\hline
\end{tabular}

Total responden pada penelitian ini adalah sebanyak 236 orang. Berdasarkan tabel 3, tingkat Quarter life crisis responden pada penelitian kebanyakan berada pada tahap sedang yaitu 102 responden (43.22\%), dilanjutkan pada kategori tinggi sebanyak 66 responden (27.97\%), seterusnya berada pada kategori rendah sebanyak 35 responden (14.83\%), kemudian sangat tinggi sebanyak 34 responden (10.17\%) dan terakhir pada kategori sangat rendah yaitu sebanyak 9 responden $(3.82 \%)$. 
Analisis selanjutnya adalah analisis korasli pearson dengan beberapa variabel demografi. Berikut data hasil analisisnya ;

Tabel 4.

Analisis korelasional variabel bebas dan terikat

\begin{tabular}{llrrr}
\hline & & Jenis_Kelamin & Pekerjaan & Status \\
\hline Jenis_Kelamin & Pearson Correlation & 1 & & \\
& Sig. (2-Tailed) & & & \\
\multirow{5}{*}{ Pekerjaan } & $\mathrm{N}$ & 236 & & \\
& Pearson Correlation & $.147^{*}$ & 1 & \\
& Sig. (2-Tailed) & .024 & & \\
\multirow{5}{*}{ Status } & $\mathrm{N}$ & 236 & 236 & \\
& Pearson Correlation & $.155^{*}$ & $-.208^{* *}$ & 1 \\
& Sig. (2-Tailed) & .017 & .001 & \\
& $\mathrm{~N}$ & 236 & 236 & 236 \\
\hline
\end{tabular}

Analisis hubungan di antara keseluruhan variabel yang diteliti dilakukan dengan analisis korelasional dari Pearson. Hasil analisis selengkapnya dapat dilihat pada Tabel 4, yang secara garis besar menunjukkan bahwa Quarter life crisis berkorelasi signifikan $(\mathrm{p}<0.05)$ dengan jenis kelamin, pekerjaan dan status.

\section{PEMBAHASAN}

Responden pada penelitian berjumlah 236 orang dan didominasi oleh wanita sebanyak 170 orang dan pria berjumlah 76 orang. Kemudian dilanjutkan dengan responden yang lebih banyak berpendidikan terakhir Sarjana (S2) dengan 115 orang yang sudah memiliki pekerjaan tetap dan 72 orang yang belum bekerja. Kebanyak responden penelitian ini berstatus belum menikah yaitu sebanyak 125 responden (53). Berdasarkan analisis yang dilakukan, diketahui Quarter life crisis yang dialami oleh dewasa awal di Pekanbaru berada pada tahap sedang dan kemudian dilanjutkan dengan tahap tinggi. Tingkat Quarter life crisis responden pada penelitian kebanyakan berada pada tahap sedang yaitu $43.22 \%$, dilanjutkan pada kategori tinggi sebesar $27.97 \%$, seterusnya berada pada kategori rendah sebesar 14.83\%, kemudian sangat tinggi $10.17 \%$ dan terakhir pada kategori sangat rendah yaitu $3.82 \%$. Hal ini berarti sebagian besar individu yang berada pada tahap dewasa awal di Pekanbaru mengalami Quarter life crisis.

Quarter Life Crisis mempengaruhi 86\% dari generasi millenial, yang menemukan bahwa generasi tersebut mengalami kegelisahan kekecewaan, kesepian, dan depresi (Stapleton, 2012). Hasil penelitian ini sejalan dengan survei yang dilakukan Gumtree.com, 86 persen dari 1.110 responden di Inggris menyatakan pernah melalui Quarter Life Crisis, 
Icha Herawati \& Ahmad Hidayat | Quarterlife Crisis

dan 32 persen diantara mereka menyatakan adanya tekanan yang besar untuk menikah dan punya anak, maksimal pada usia 30.

Hasil penelitian menunjukkan responden kebanyakan berada pada tahap sedang yaitu 102 responden (43.22\%) hal ini sejalan dengan penelitian oleh (Robbins, 2004) yang menyatakan bahwa individu pada usia 20-an mengalami kebingungan mengenai identitasnya, merasa frustasi dengan hubungan dan karir, merasa kecewa dengan semua hal, hingga merasa sangat khawatir dengan kelangsungan hidupnya sebagai orang dewasa. Hal tersebut dialami oleh individu dalam memasuki fase dewasa awal dalam menghadapi realitas dunia yang terkesan menjadi sulit dan berat karena individu tidak memiliki cukup persiapan untuk menghadapinya.

Sebanyak 58\% responden penelitian ini sudah menyelesaikan pendidikan Sarjana sehingga mereka berapa pada tahap untuk melanjutkan kehidupan selanjutnya yaitu melanjutkan perkuliahan, bekerja atau menikah. Menurut Fischer (2008) quarter life crisis adalah perasaan khawatir yang hadir atas ketidakpastian kehidupan mendatang seputar relasi, karier, dan kehidupan sosial yang terjadi sekitar usia 20-an. Mendukung pernyataan tersebut Chesbrough (2011) mengatakan bahwa yang dihadapi ketika mengalami quarter life crisis adalah masalah terkait mimpi dan harapan, tantangan kepentingan akademis, agama dan spiritualitasnya, serta kehidupan pekerjaan dan karier.

Hasil penelitian ini juga menunjukkan responden lebih banyak yang belum menikah dan berstatus single. Hal tersebut juga berpengaruh terhadap Quarter life crisis yang menyatakan bahwa terdapat dua jalan yang biasanya ditempuh oleh individu ketika memasuki usia 20 tahun, hal pertama yaitu karier dan yang kedua adalah percintaan (Robbins, 2004). Quarter life crisis merupakan krisis kehidupan yang dialami oleh individu yang memasuki usia 20 tahun sampai 30 tahun. Sehingga, apa yang dialami oleh inidividu dewasa awal di Pekanbaru merupakan suatu proses krisis kehidupan yang banyak dialami oleh individu pada tahap perkembangannya. Quarter life crisis merupakan tahap kehidupan ketika individu yang berusia 25 tahunan mempertanyakan tentang hidupnya. Pada masamasa yang merupakan puncak kedewasaan seseorang ini, ia akan mulai meninjau kembali masa lalunya, apa yang telah dilakukan dimasa lalu, apa yang telah dapatkan, dan bagaimana kehidupannya di masa datang (Revitasari, 2018).

Pada majalah Forbes, permasalahan pekerjaan dipandang oleh generasi terdahulu bahwa tujuan utama bekerja adalah hanya untuk mendapat uang semata, sedangkan bagi sebagian individu dewasa awal saat ini merasa bahwa pekerjaan yang sesuai idamanlah yang patut dikejar serta mesti memenuhi kebutuhan aktualisasinya dan harus terkait hal yang mereka disenangi. Penyebab krisis ini sendiri adalah adanya tekanan dan tuntutan 
dari lingkungan sekaligus diri sendiri dalam pencapaian hidup beserta mimpi-mimpi yang belum tercapai. Sebab kerasnya hal tersebut menimpa seseorang dapat berakibat menekan psikis seseorang hingga dapat berada dalam Quarter Life Crisis.

Inidividu yang memasuki usia dewasa perlu membentuk hubungan dekat dan cinta dengan orang lain. Cinta yang dimaksud tidak hanya mencakup hubungan dengan kekasih namun juga hubungan dengan orang tua, tetangga, sahabat, dan lainnya. Quarter life crisis juga didasari pada mitos yang berkembanga pada masyarakat mengenai wanita, yaitu bahwa wanita tidak memerlukan pendidikan yang tinggi, sehingga pendidikan yang tinggi tersebut akan membuat seorang wanita cemas akan hidupanya dikarenakan mitos tersebut (Primala, 2017).

Berdasarkan data demografi yang yang didapatkan dari penelitian ini adalah masih banyak individu dewasa awal di Pekanbaru yang belum bekerja, sehingga faktor tersebut menjadi salah satu penyebab Quarter life crisis, sesuai dengan penelitian oleh (Basis, 2014) yang menemukan bahwa salah satu aspek yang meningkatkan kualitas hidup dewasa awal adalah bekerja. Keinginan individu dewasa awal yang biasanya baru saja menyelesaikan sekolah atau perkuliahan memiliki keinginan untuk berkarier sebelum menikah, atau meneuruskan pendidikan ke jenjang yang lebih tinggi. Namun pada kenyataanya terdapat individu dewasa awal yang belum dapat memiliki pekerjaan yang diinginkan dan juga terdapat hal-hal lain yang mendorongnya untuk menunda pernikahan atau berumah tangga sehingga menjadi faktor pemicu Quarter life crisis.

Tahapan perkembangan psikososial Erikson menyatakan pada usia dewasa adalah Keintiman vs isolasi (intimacy versus isolation) adalah tantangan pada usia dewasa muda, hal terpenting pada tahap ini adalah adanya suatu hubungan (Robinson dkk., 2013). Tahapan perkembangan psikososial pada usia dewasa adalah Pada tahap ini individu sudah mulai selektif membina hubungan yang intim, hanya dengan orang-orang tertentu yang sepaham. Jadi pada tahap ini timbul dorongan untuk membentuk hubungan dengan orang lainnya. Pemahaman dalam kedekatan dengan orang lain mengandung arti adanya kerjasama yang terjalin dengan orang lain. Akan tetapi, peristiwa ini akan memiliki pengaruh yang berbeda apabila seseorang dalam tahap ini tidak mempunyai kemampuan untuk menjalin relasi dengan orang lain secara baik sehingga akan tumbuh sifat merasa terisolasi.

Fenomena quarter-life crisis cenderung terjadi dalam kurun waktu satu tahun, namun bisa lebih cepat maupun lebih panjang tergantung kepada cara individu melewatinya. (Robbins, 2004) menyebutkan bahwa individu yang mengalami krisis adalah individu-individu yang kesulitan melakukan penyesuaian terhadap tuntutan yang berasal 
Icha Herawati \& Ahmad Hidayat | Quarterlife Crisis

dari dirinya sendiri maupun tuntutan dari orang tua, keluarga, dan lingkungan sosial. Krisis akan muncul ketika individu tidak memiliki pedoman untuk menghadapi segala tuntutan dan harapan yang muncul di awal usia 20 tahun ini. Individu yang mengalami quarter-life crisis disarankan untuk memiliki coping mechanism dalam menghadapi berbagai tekanan dalam quarter-life crisis (Atwood \& Scholtz, 2008). Bentuk dari coping mechanism ini adalah latihan fisik yang dapat memberikan pengaruh untuk meningkatkan suasana hati menjadi lebih baik. Selanjutnya, melakukan talking therapy, yaitu individu dapat mencoba untuk berbagi pikiran dan perasaannya dengan orang-orang terdekat dengan tujuan untuk memberikan efek terapeutik agar individu merasa tidak sendirian. Kemudian melatih diri untuk berpikir positif, yaitu mengontrol pikiran negatif menjadi hal-hal yang lebih dapat diterima dan mau terbuka pada berbagai pendapat dan pilihan.

Individu yang mengalami quarter-life crisis cenderung karena memiliki harapan yang terlalu tinggi mengenai kehidupan dan karir sehingga menyebakan perasaan kecewa ketika kehidupan dewasa tidak sesuai yang dimimpikan ketika remaja (Stapleton, 2012). Secara umum, masih banyak individu yang berada pada tahap dewasa awal mengalami quarter-life crisis, sehingga terdapat beberapa langkah yang dapat dilakukan untuk menghadapi krisis psikososial tersebut diantara dengan melibatkan peranan orangtua (Habibie dkk., 2019), menyibukkan diri dengan pekerjaan (Basis, 2014), meningkatkan resilensi (Balzarie \& Nawangsih, 2019), mempelajari keterampilan baru (Stapleton, 2012) dan menyadari bahwa hal ini merupakan proses kehidupan yang akan terlewati.

\section{SIMPULAN}

Hasil penelitian menujukkan bahwa Quarter life crisis individu dewasa awal di Pekanbaru berada pada tahap sedang yaitu 43.22\%, dilanjutkan pada kategori tinggi sebesar 27.97\%. Hasil penelitian juga menunjukkan bahwa jenis kelamin, status dan pekerjaan berhubungan dengan Quarter life crisis. Hasil penelitian ini tidak hanya memberikan manfaat secara teoritis, namun juga praktis. Secara praktis, penelitian ini dapat memberikan manfaat yang bertumpu kepada keterkaitan individu yang akan memasuki tahap dewasa awal sebagai acuan memahami krisis kehidupan yang dialaminya. Bahkan, penelitian ini bisa menjadi acuan dalam memberikan pandangan kepada pihakpihak yang berkenaan terhadap program pengembangan konseling perkembangan dan sosial. 


\section{DAFTAR PUSTAKA}

Atwood, J. D., \& Scholtz, C. (2008). The quarter-life time period: An age of indulgence, crisis or both? Contemporary Family Therapy, 30(4), 233-250. https://doi.org/10.1007/s10591-008-9066-2

Balzarie, E. N., \& Nawangsih, E. (2019). Kajian Resiliensi pada Mahasiswa Bandung yang Mengalami Quarter Life Crisis Istilah emerging adulthood dikemukakan pertama kali oleh Arnett sering kali stres, khawatir dan merasa depresi yang disebabkan oleh kondisi.

Basis, L. (2014). Perbedaan Kualitas Hidup pada Dewasa Awal yang Bekerja dan yang Tidak Bekerja. Jurnal Psikologi Industri dan Organisasi, 3(2), 2-4.

Chesbrough, R. D. (2011). Helping College Students Find Purpose: The Campus Guide to Meaning-Making. Journal of College Student Development, 52(4), 505-507. https://doi.org/10.1353/csd.2011.0049

Fischer, K. (2008). Ramen noodles, rent and resumes: An after-college guide to life. SuperCollege.

Habibie, A., Syakarofath, N. A., \& Anwar, Z. (2019). Peran Religiusitas terhadap Quarter-Life Crisis (QLC) pada Mahasiswa. Gadjah Mada Journal of Psychology (GamaJoP), 5(2), 129. https://doi.org/10.22146/gamajop.48948

Halfon, N., Forrest, C. B., Lerner, R. M., \& Faustman, E. M. (2017). Handbook of life course health development. Handbook of Life Course Health Development, 1-664. https://doi.org/10.1007/978-3-319-47143-3

Kirsh, S. J., Duffy, K. G., \& Atwater, E. (2013). Psychology for Living: Adjustment, Growth, and Behavior Today (11 edition). Pearson.

Macrae, F. (2011). Quarter-life' crisis hits three in four of those aged 26 to 30. https://www.dailymail.co.uk/news/article-1289659/Quarter-life-crisis-hits-2630-year-olds.html

Noor, H. (2018). Rentan mendera usia 25-an, kenali quarter life crisis \& 9. https://www.brilio.net/kepribadian/rentan-mendera-usia-25-an-kenali-quarterlife-crisis-9-solusinya-180803n.html

Primala, D. A. (2017, Mei 1). Ada Apa dengan Quarter Life Crisis? Pijar Psikologi. https://pijarpsikologi.org/ada-apa-dengan-quarter-life-crisis/

Revitasari, F. (2018). 9 Tanda Quarter Life Crisis, Sudahkah Kamu Giliran Mendapatinya? IDN Times. https://www.idntimes.com/life/inspiration/vita/9-tanda-quarter-lifecrisis

Robbins, A. (2004). Conquering your quarterlife crisis: Advince from twentysomethings who have been there and survived. http://dx.doi.org/10.1016/S1876-6102(11)01402-0

Robinson, O. C., Wright, G. R. T., \& Smith, J. A. (2013). The Holistic Phase Model of Early Adult Crisis. Journal of Adult Development, 20(1), 27-37. https://doi.org/10.1007/s10804-013-9153-y 
Icha Herawati \& Ahmad Hidayat | Quarterlife Crisis

Stapleton, A. (2012). Coaching Clients through the Quarter-Life Crisis: What works? International Journal of Evidence Based Coaching and Mentoring, 6, 130-145.

Vasquez, J. P. R. (2015). Development and Validation of Quarterlife Crisis Scale for Filipinos. The Asian Conference on Psychology \& the Behavioral Sciences Development, April 2015, 447-459.

Wardhani, V. (2002). Gambaran kualitas hidup dewasa muda berstatus lajang melalui adaptasi instrumen Whoqol-Bref dan SRPB. Thesis. 